\title{
Impacts of the agricultural transformation of the Canadian Prairies on grassland arthropods
}

\author{
M.A. Vankosky, ${ }^{1}$ H.A. Cárcamo, H.A. Catton, A.C. Costamagna, R. De Clerck-Floate
}

\begin{abstract}
The prairie grasslands have been transformed to become the primary source of agricultural production in Canada. Soon after its establishment, the Biological Survey of Canada recognised the urgent need to document the arthropods of the prairie grasslands, especially in the few pristine remnants. Although this initiative has yielded considerable progress in documenting the species present in the Prairies Ecozone, comprehensive ecological studies are sparse. Landscape effects on arthropods are well studied elsewhere, but no equivalent studies have been published for the Canadian Prairies. Crop rotation varies landscape composition annually, changes host plant resources in fields, and interacts with other agricultural inputs to disturb pest and beneficial arthropods. Despite only a handful of studies on grazing, there is an emerging pattern: moderate grazing increases arthropod diversity and benefits certain arthropod guilds. Abiotic inputs elicit variable responses from different arthropod taxa; Carabidae (Coleoptera) are best studied, with some information available for ants (Hymenoptera: Formicidae) and aquatic arthropods. Biotic inputs include arthropods released for biocontrol of weed and insect pests; evidence indicates that biocontrol agents of insects have a greater potential for impact on native communities of arthropods. The studies reviewed here reveal important trends and research gaps to be addressed in the future.
\end{abstract}

\section{Introduction}

At least $75 \%$ of the lands originally covered by grasslands are now used for grazing livestock or crop cultivation in the Canadian Prairies (Rowe 1990). There are 52000000 ha of Canadian farmland located in Manitoba, Alberta, and Saskatchewan, which accounted for $81 \%$ of the area farmed in Canada in 2011 (Statistics Canada 2012). As a result of this agricultural expansion, $<1 \%$ of the tallgrass prairie remains in Canada, with the remnants occurring in small fragments in southern Manitoba and southwestern Ontario (Chliboyko 2010; Shorthouse 2010). In other ecoregions, such as the Mixed Grasslands, the proportion of native grassland that remains relatively unaltered could be as high as $30 \%$ (Hall et al. 2011).

The Prairies Ecozone now consists of grasslands, disturbed grasslands (i.e., grazed land and hay fields), and cropland. Croplands (or agroecosystems) are dominated by spring-sown annual cereals, oilseeds, pulses, and perennial forage crops, grown in monoculture and maintained under high levels of disturbance (Martens et al. 2015). Croplands feature similar timing of agronomic activities, crop rotation schemes, soil disturbances of varying degrees, and chemical and organic inputs to manage soil fertility and agricultural pests. Agricultural practices vary spatially and temporally on an annual basis and can have significant impacts on the diversity and structure of arthropod communities (McLaughlin and Mineau 1995; Olfert et al. 2002). Arthropod communities include a few pest species that threaten crop production but many species have neutral effects or provide valuable ecosystem services such as natural pest control, improvements to soil quality, and pollination (Pimentel 2009). Understanding arthropod communities is important

Received 4 May 2017. Accepted 28 June 2017. First published online 6 October 2017.

M.A. Vankosky, ${ }^{1}$ Agriculture and Agri-Food Canada, 107 Science Place, Saskatoon, Saskatchewan, S7N 0X2, Canada

H.A. Cárcamo, H.A. Catton, R. De Clerck-Floate, Agriculture and Agri-Food Canada, 5403 1st Avenue S, Lethbridge, Alberta, T1J 4B1, Canada

A.C. Costamagna, Department of Entomology, Room 217 Entomology Building, University of Manitoba, Winnipeg, Manitoba, R3T 2N2, Canada

${ }^{1}$ Corresponding author (e-mail: Meghan.Vankosky@canada.ca).

Subject editor: Donna Giberson

doi: $10.4039 /$ tce. 2017.47 
for the conservation of ecosystem services and subsequently, for agricultural sustainability.

Biodiversity studies of arthropods conducted in pristine grassland habitats are sparse. Arthropods have been widely studied in agroecosystems, including grazed grasslands. However, most studies have focused on species of economic importance (i.e., pests and their natural enemies) and cannot be considered biodiversity studies. An exception is the comprehensive study of alfalfa by Harper (1988) that listed 446 insect and mite (Acari) species using a variety of sampling methods near Lethbridge, Alberta. Studies that directly compare arthropod communities in agroecosystems to those in pristine or disturbed grasslands are also rare. Biodiversity studies conducted in agroecosystems of the Canadian Prairies focus primarily on carabid beetles (Coleoptera: Carabidae) (Holliday et al. 2014), although some information on other taxa, such as ants (Hymenoptera: Formicidae) is available. The Biological Survey of Canada has been instrumental in advancing our knowledge of Prairies Ecozone arthropods (Floate et al. 2017). One of its volumes is largely devoted to prairie agroecosystems (Floate 2011). DNA barcoding of samples captured in Malaise traps in the Grasslands National Park may also provide some insight to arthropod biodiversity in the Canadian Prairies (Biodiversity Institute of Ontario 2013).

Our objective is to synthesise studies on the effects of agriculture on arthropod diversity in the Canadian Prairies. First, we consider effects of landscape characteristics, such as fragmentation and the proportion of non-crop habitat on arthropod biodiversity. Second, we consider the effects of agricultural practices that alter arthropod habitats by affecting the primary vegetation structure. Finally, we review the effects of abiotic and biotic agricultural inputs for pest and weed management. Where evidence from the Canadian Prairies is unavailable, we rely on examples from other jurisdictions to provide an overview of concepts to highlight research gaps and provide the foundation for future studies.

\section{Landscape-scale impacts: theory and concepts}

Despite increasing recognition that the abundance and diversity of arthropods is highly influenced by landscape structure (Benton et al. 2003; Chaplin-Kramer et al. 2011; Fahrig et al. 2011), very little research has been conducted at this scale in the Canadian Prairies. To illustrate the importance of the ecological processes taking place at the landscape scale on determining arthropod diversity in agroecosystems, we briefly introduce the main concepts of the landscape approach. We then highlight the most important patterns arising from the data currently available for grasslands in Canada and elsewhere.

Due to spatial and temporal instability across agricultural landscapes, arthropods periodically colonise agroecosystems, particularly after the emergence of a new crop, following perturbations, or to forage for alternative resources (Wiedenmann and Smith 1997; Wissinger 1997; Landis et al. 2000). Therefore, the arrangement of habitats and resources in agricultural landscapes may affect the population dynamics of arthropods in agroecosystems. The effects of landscape structure on arthropod diversity are classified into two broad categories: effects of landscape composition (i.e., quantity and quality of habitats within the landscape), and landscape configuration (i.e., relative distribution of habitats and their effects on arthropod movement). The proportion of non-crop (natural or semi-natural) habitats is an estimate of landscape structure (Bianchi et al. 2006; Chaplin-Kramer et al. 2011; Veres et al. 2013). In general, landscapes with a high proportion of non-crop habitats are classified as complex, whereas landscapes dominated by crops are simple. Since non-crop habitats provide many resources absent in crops, ecological theory predicts that complex landscapes have greater abundance and diversity of arthropods, and higher levels of related ecosystem services (Bianchi et al. 2006; Chaplin-Kramer et al. 2011; Tscharntke et al. 2012; Veres et al. 2013).

Landscape structure is expected to moderate patterns of arthropod population dynamics, community structure, and ecosystem function, with positive effects on alpha and beta diversity (Tscharntke et al. 2012). At the landscape scale, resources are available at different temporal and spatial scales; this transient concentration or dilution of resources leads to subsequent concentration or dilution of arthropod taxa. For example, mass flowering of oilseed rape (Brassica napus Linnaeus; Brassicaceae) can dilute pollinator density 
and pollination services to wild flowers in natural grasslands (Holzschultz et al. 2011). Increased biodiversity associated with landscape heterogeneity can result in greater levels of species complementarity and redundancy, providing insurance to maintain ecosystem function and resilience at multiple scales. Landscapes with intermediate levels of complexity are thought to be the most promising for conservation management, with the addition of semi-natural habitat expected to restore biodiversity and ecosystem function (Tscharntke et al. 2012). However, there is hope for highly simplified landscapes (i.e., "cleared" landscapes, $<1 \%$ non-crop habitat), as flowering strips in cleared landscapes increase diversity of bees and hoverflies (Kremen and M'Gonigle 2015).

The effects of landscape complexity cannot be generalised to all agricultural systems, and may not always be beneficial. For example, non-crop habitats can provide resources that support pest populations, sometimes cancelling out the benefits of increased natural enemy populations (Thies et al. 2005). Moreover, the relationship between landscape structure, population dynamics, and ecosystem services varies temporally. Seasonal changes in habitats provide resources for arthropods in agricultural landscapes suggesting that both spatial and temporal heterogeneity of resources is important (Chaplin-Kramer et al. 2013; Schellhorn et al. 2015). A more thorough understanding of temporal and spatial variability in agricultural landscapes could be used to design agroecosystems with sustainable levels of ecosystem services (Tscharntke et al. 2016; Landis 2017).

\section{Grasslands in agricultural landscapes}

Only small fragments of grasslands, with a rich diversity of fauna, still exist isolated in agricultural landscapes (Tscharntke et al. 2002; De Clerck-Floate and Cárcamo 2011). Here we define pastures and hayfields, managed for production, as disturbed grasslands. Disturbed grassland habitats are more perennial compared to croplands planted to annual field crops (Werling et al. 2014). Recent studies suggest that permanent and temporary grasslands (natural or disturbed) have positive effects on carabid richness, compared with other non-crop habitats, such as hedgerows and woodlands (Duflot et al. 2015). In the Midwestern United States of America, carabid beetles, spiders (Araneae), and native Coccinellidae (Coleoptera) were more abundant in soybean (Glycine max (Linnaeus); Fabaceae) fields located in landscapes with higher proportions of natural and disturbed grasslands (Gardiner et al. 2009, 2010). In The Netherlands, parasitism of Mamestra brassicae (Linnaeus) (Lepidotera: Noctuidae) in Brussels sprout (Brassica oleracea Linnaeus; Brassicaceae) fields increased with the proportion of pastures in the landscape (Bianchi et al. 2005). These studies suggest that grasslands are good reservoirs of insect biodiversity and may act as sources of beneficial insects for adjacent crops in agricultural landscapes, although there are exceptions. For example, the proportion of grassland habitats in the landscape is not associated with abundance of wheat stem sawfly (Cephus cinctus Norton; Hymenoptera: Cephidae) or its native parasitoids in the northern Great Plains (Rand et al. 2014).

A few studies have been conducted to assess landscape effects on arthropod diversity in eastern Canadian agroecosystems. In Ontario, Jonsen and Fahrig (1997) found that landscape diversity increased the diversity of herbivorous insects in the families Curculionidae (Coleoptera) and Cicadellidae (Hemiptera) in alfalfa fields. Similarly, Holland and Fahrig (2000) found that alfalfa fields in landscapes with high proportions of woody borders have greater herbivore richness. Flick et al. (2012) demonstrated greater butterfly (Lepidoptera) richness in more heterogeneous agricultural landscapes. A large-scale study that consisted of $931-\mathrm{km}^{2}$ landscapes showed that reduced field size was the main predictor of spider, butterfly, hover fly (Diptera: Syrphidae), bee (Hymenoptera), and carabid beetle diversity, but crop area and crop diversity had no effect (Fahrig et al. 2015). In Québec, Mitchell et al. (2014) found that wider soybean fields have lower diversity and abundance of aphidophagous predators and herbivores. Maisonhaute et al. (2010) found significant but variable landscape effects on ground beetle and tiger beetle (Coleoptera: Carabidae) abundance and diversity in agricultural landscapes. In general, some individual non-crop variables (i.e., riparian vegetation, pasture area, and woodland area) showed positive 
associations with beetle diversity, but habitat diversity had negative effects (Maisonhaute $e t$ al. 2010). In soybean, the proportion of woodland cover increased natural enemy density and functional diversity, and enhanced biocontrol (Maisonhaute et al. 2017).

In western Canada, Pepper (1999) studied the impact of pasture size on spiders and beetles in the Mixed Grassland Ecoregion in southern Saskatchewan. Her results indicated that species richness increased with the log-area of the pasture, and rare species occurred more often in larger pastures (Pepper 1999). Carabidae, Apion amaurum Kissinger (Coleoptera: Brentidae), and the sac spider (Clubiona mutata Gertsch; Araneae: Clubioidae), were indicator taxa that separated "poor quality" small pastures from larger "good quality" pastures (Pepper 1999). This study considered the size and range condition of the study sites, but did not consider how other landscape features impacted these taxa. So far as we are aware, no other studies that explicitly consider arthropod diversity in relation to landscape structures have been conducted in western Canada. We need to fill this knowledge gap by conducting research at the landscape scale in the Canadian Prairies. It would be of particular interest to assess the impact of specific landscape characteristics (e.g., the proportion of wetlands, the proportion of perennial versus annual crops, and crop diversity) on arthropod biodiversity and subsequently on the ecosystem services that arthropods provide in agroecosystems.

\section{Vegetation structure: crop rotation}

Crop rotation (or crop succession) is the practice of growing different crops on the same piece of land in successive years (Yates 1954), and is known to improve yields and reduce pest pressure (Bullock 1992). Rotations vary in the crops that are planted, the number of crop species included in the rotation, and the frequency of planting a given crop. Rotations can include fallow periods when no crop is grown. In Canada, rotations are becoming more diversified, due to increasing popularity of oilseeds, pulses, and specialty crops in recent decades (Campbell et al. 2002). Recent data indicated that prairie farmland in fallow has decreased from 9\% in 2001 to $4 \%$ in 2011
(Statistics Canada 2012). Although crop rotation is used to control pest insects, it may impact other arthropods as well.

Changing crop species from year-to-year alters the habitat in a given field. Crop species determine microclimates within the crop canopy, and the type, quality, and timing of food resources that arthropods encounter. Crop species also leave different soil-surface residues, require different inputs (e.g., pesticides, fertilisers), and have different disturbance regimes (e.g., harvesting, tillage). These factors affect arthropod behaviours, life histories, and predator-prey dynamics at various life stages, thus influencing arthropod community structure and richness. Because of interactions between crop species and inputs, it can be difficult to tease apart the effects of crop rotation from the effects of inputs associated with different rotational schemes (Smith et al. 2008). For example, diversified rotations are often accompanied by reduced pesticide use; therefore, changes in the arthropod community could be attributed to the effects of crop diversity, reduced insecticide inputs, or both factors (e.g., Cárcamo and Spence 1994). Carefully designed studies where both inputs and rotations were manipulated have been conducted, with mixed results. A few studies have demonstrated that crop rotation can have a greater impact on arthropod populations than changes in agricultural inputs (Brust and King 1994; Melnychuk et al. 2003).

Collectively, crop rotations determine the spatial and temporal mosaic of host plant resources at the landscape level (Ahern and Brewer 2002; Bertrand et al. 2016). The response of arthropod species to crop rotation depends on the interaction between their ability to tolerate changes in local habitat and their dispersal ability (Bertrand et al. 2016). Specialist arthropods with high host fidelity and low dispersal abilities are most affected (Flint and Roberts 1988). On the Canadian Prairies, the native cereal pest, wheat stem sawfly fits these criteria, and rotation away from wheat has been recommended and practiced for decades (Beres et al. 2011). Also in western Canada, Dosdall et al. (2012) compared canola (Brassica napus Linnaeus; Brassicacaea) yields and root maggot (Delia Robineau-Desvoidy; Diptera: Anthomyiidae) damage in 12 three-year rotations ranging from canola in only one year to canola in all three years at five locations and found that 
continuous canola cropping increased root maggot damage. Crop rotation has also effectively managed populations of the western corn rootworm (Diabrotica virgifera virgifera LeConte; Coleoptera: Chrysomelidae) and the northern corn rootworm (Diabrotica barberi Smith and Lawrence; Coleoptera: Chrysomelidae) in the United States of America (Spencer et al. 2014).

Crop rotations can affect specialist insects that are able to migrate or disperse. For example, crop rotation forces adult Colorado potato beetles (Leptinotarsa decemlineata Say; Coleoptera: Chrysomelidae) to disperse from their emergence sites (near the potato (Solanum tuberosum Linnaeus; Solanaceae) crop of the previous season) to suitable potato fields in the spring. In general, as insect dispersal distance increases, the chance of finding suitable hosts, insect survival rate, and the amount of energy left for reproduction decreases. Therefore, the efficacy of dispersal distance as a pest control tactic depends on the size of the insect population. The minimum effective distance between fields required to reduce potato beetle populations was determined to be $100 \mathrm{~m}$ when beetle densities were low (Boiteau et al. 2008) and more than $400 \mathrm{~m}$ when beetle densities were high (Sexson and Wyman 2005).

Specialist pests can overcome crop rotation, especially those capable of dispersing long distances, accurate host location, or of survival in the absence of their preferred host plants (Bullock 1992; Capinera 2005). For example, populations of the diamondback moth (Plutella xylostella (Linnaeus); Lepidoptera: Plutellidae) passively disperse into the Canadian Prairies on prevailing wind currents from the United States of America and can reach canola fields regardless of their location or the rotation schedule (Dosdall et al. 2011). In addition, diamondback moths use cruciferous weeds as alternative hosts, further facilitating dispersal (Dosdall et al. 2011). Similarly, grassy weeds or volunteer wheat (Triticum aestivum Linnaeus; Poaceae) provide "green bridges" for wheat curl mites (Aceria tosichella Keifer; Acari: Eriophyidae), the vector of wheat streak mosaic virus, for mite survival between spring wheat and winter wheat crops (Gillespie et al. 1997). Finally, in recent decades the northern and western corn rootworms have developed resistance to crop rotation through increased dormancy and reduced host specificity (reviewed by Spencer et al. 2014).

Compared with specialist herbivores, generalists are less vulnerable to effects of crop rotation. Wireworms (Coleoptera: Elateridae) are widespread and often reach pest status in the Canadian Prairies (van Herk and Vernon 2014). The subterranean larvae of the 30 pest wireworm species in Canada can survive for three to five years and can consume most crops. Because wireworms are generalists, crop rotation is not generally a viable control option. Three examples of successful rotational control of wireworm have been documented. Successful rotations included a fallow year without potential host plants, as observed in Washington, United States of America (Esser et al. 2015); inclusion of biofumigant crops such as brown mustard (Brassica juncea (Linnaeus); Brassicaceae), as observed on Prince Edward Island (Agriculture and Agri-Food Canada 2010); and the inclusion of less preferred host crops such as tobacco (Nicotiana tabacum Linnaeus; Solanaceae), as observed in North Carolina, United States of America (Willis et al. 2010).

Beneficial arthropods can be affected by crop rotation (Brust and King 1994). Research conducted on the Canadian Prairies has shown that relationships between carabid beetles and crop rotation are complex. Cárcamo et al. (1995) found that species richness, diversity, and evenness of carabids near Edmonton, Alberta did not differ between monocultures of barley (Hordeum vulgare Linnaeus; Poaceae), faba bean (Vicia faba Linnaeus; Fabaceae), an intercrop of barley with pea (Pisum sativum Linnaeus; Fabaceae), or with crop rotation. However, in a related mark-releaserecapture experiment, individuals of the adventive, dominant, and mobile carabid Pterostichus melanarius (Illiger) (Coleoptera: Carabidae) entered the intercrop more often than the monocultures, suggesting an effect of vegetation structure on habitat choice for this species (Cárcamo and Spence 1994). At Vauxhall, Alberta, Bourassa et al. (2008) found that carabid species composition differed among small plots of wheat, bean (Phaseolus vulgaris Linnaeus; Fabaceae), and potato. Potato plots had lower carabid activity density than wheat and bean plots, but the crops did not differ in terms of diversity, and there were species-specific responses to crop species (Bourassa et al. 2008). However, other agricultural practices and inputs varied between the crops in the 
rotation, confounding the results (Bourassa et al. 2008).

Few studies have examined the effects of different crop rotation patterns on non-pest arthropod communities. Osler et al. (2008) compared soil mite communities over two years in sweet clover (Melilotus officinalis (Linnaeus); Fabaceae) in organic and low input systems with different rotation diversity (two versus four crop species) near Lethbridge. In one year, the organic system with the four crop rotation supported greater mite abundance and diversity; however, the impact of the rotation diversity was small relative to annual variation in abiotic conditions (Osler et al. 2008). Ellsbury et al. (1998) compared carabid assemblages over two years in plots of wheat, corn, soybean, and alfalfa following four different rotations in South Dakota and found carabid richness and diversity was highest in the most diverse rotational treatment (Ellsbury et al. 1998). Humble (2001) compared carabid communities in southern Manitoba flax (Linum usitatissimum Linnaeus; Linaceae) crops following three different rotations of annual crops rotated with forage crops and observed inconsistent effects of rotation on the composition of carabid communities. The diversity and evenness of carabid communities in flax plots did not depend on the crops in the previous rotation (Humble 2001). Species-specific responses occurred where seedfeeders such as Amara Bonelli and Harpalus Latreille (Coleoptera: Carabidae) were associated with rotation of annual crops and higher weed densities (Humble 2001).

Evidence suggests that carabid beetles respond more strongly to the current vegetation structure than to previous crops planted on the same field. For example, Melnychuk et al. (2003) compared input levels and rotations (annual grain rotations versus diversified grain-forage rotations) in Saskatchewan. They observed that species diversity was higher in annual grain rotations, possibly because of the more open canopies in the cereal crops compared to the broadleaf crops (Melnychuk et al. 2003). In corn rotations near Lethbridge, cornfields rotated with canola had high activity densities (number of individuals captured per pitfall trap per day of sampling) of larger-bodied carabids such as Amara farcta LeConte (Coleoptera: Carabidae), Amara littoralis Mannerheim (Coleoptera: Carabidae), Pterostichus melanarius, and Poecilus corvus (LeConte) (Coleoptera:
Carabidae) and low activity densities of smallerbodied carabids such as Bembidion Latreille (Bourassa et al. 2010). The response of large-bodied beetles was attributed to increased soil moisture, increased habitat complexity for prey, and additional food resources resulting from soil-surface canola mulch residues (Bourassa et al. 2010). The same residues likely impeded the movement of smallbodied species between plots (Bourassa et al. 2010). We could find no examples of longitudinal studies to compare carabid community composition through multiple field seasons in the Canadian Prairies. Work of this nature is needed to determine longer-term trends.

Parasitoids and other non-pest arthropods must overcome obstacles presented by crop rotation. Ahern and Brewer (2002) found that two species of specialist aphid parasitoids benefited from the spatial configuration resulting from more diverse crop rotations in Wyoming and Colorado, United States of America. Recent studies suggest that carabids and other mobile beneficial insects such as parasitoids may be more affected by regional landscape factors than by local field conditions (Maisonhaute et al. 2010; Bertrand et al. 2016).

Crop rotation is an important pest management tool that can have implications for arthropod pests, and for beneficial arthropods that provide important agroecosystem services. Understanding the effects of crop rotation on arthropod biodiversity is challenging because of confounding factors (Smith et al. 2008). However, more information is required to address how crop rotation impacts neutral arthropod species that inhabit prairie grassland habitats and could help guide conservation efforts.

\section{Vegetation structure: cropping practices and grazing}

The crops that farmers produce, and the scale at which they are produced, can impact arthropod diversity (Andow 1983; Altieri et al. 1984). Monocultures are associated with increasing frequency and intensity of insect pest outbreaks, because they provide highly apparent, attractive, and nutritious food resources to pests, but not to their natural enemies (Andow 1983). Monocultures have fewer edges and other pathways that predators and parasitoids use to colonise new 
habitats (Price 1976). Thus, richness and abundance of natural enemy species decline in monoculture systems because alternative prey or hosts are absent (Andow 1983). In Canada, most crops (with a few notable exceptions) are grown in large monocultures.

In the Canadian Prairies, different land management practices and cropping strategies affect arthropods. Most examples come from studies conducted on Carabidae and Formicidae. Some carabid species are affected by different cropping systems, including intercrops (Cárcamo and Spence 1994; Broatch 2008; Hummel et al. 2012). For example, Pterostichus melanarius activity was greater in canola monocultures than in wheat/ canola intercrops (Hummel et al. 2012). Other carabid and staphylinid beetles (Coleoptera: Staphylinidae) that prey upon Delia species were more active in wheat/canola intercrops (Hummel et al. 2012). Broatch (2008) observed similar impacts of intercropping on carabid diversity and density. In comparison, the activity density of carabid beetles in barley/pea and barley/canola intercrops was equal to the activity density in monocultures of those crops grown in Alberta (Butts et al. 2003). Studies conducted in Europe have demonstrated that undersown crops, or cover crops, serve to increase carabid populations, especially later in the growing season once the cover crop is established (Hance 2002). Field boundaries contribute to the diversity of vegetation in agroecosystems and provide habitat for a greater diversity of arthropods compared with crops (Olfert et al. 2005). Some pest species, including grasshoppers (Orthoptera) benefit from field boundary habitats, as well as many beneficial arthropods (Olfert et al. 2005).

Depending on definition, grazing affects half of the world's terrestrial ecosystems (Schuman et al. 2002). Grazing is a common activity in the Prairies Ecozone that has received some attention from arthropod researchers. Stjernberg (2011) compared carabid diversity in grazed and ungrazed paddocks in a tallgrass reserve in southwest Manitoba. She reported that Pasimachus elongatus LeConte (Coleoptera: Carabidae) and three other large-bodied species were part of a complex associated with grazed pastures. Stjernberg (2011) concluded that these species benefited from the higher habitat heterogeneity created by cattle in grazed paddocks. French et al. (1998) reached a similar conclusion for Pasimachus elongatus and other carabids when they used mowing to mimic grazing in a pasture reserve in central Oklahoma, United States of America. In Stjernberg's study (2011), other carabids such as Poecilus lucublandus (Say) (Coleoptera: Carabidae) that require densely vegetated habitats had higher abundance in ungrazed areas. She cautioned that such patterns might vary with grazing intensity. In Alberta, Clapperton et al. (2002) compared the diversity of soil mite families in relation to grazing in the Fescue Ecoregion near Stavely. They found a greater diversity of mite families and greater abundance of individual mite species in pastures that were lightly grazed compared with heavily grazed pastures. A few families were only found in the heavily grazed pastures (Clapperton et al. 2002), demonstrating that grazing can have significant effects on communities even at the family level. Finally, a preliminary report from the Kinsella Research Farm at the University of Alberta, in the Prairies Ecozone, reported a tentative trend of greater ant abundance and lower carabid abundance in grazed than in ungrazed pastures (Spence and Berg 1984). Spence and Berg (1984) also reported a relationship between carabid body size and grazing intensity.

Other workers have investigated the effects of grazing on ant abundance (e.g., Heron 1996; Schmidt et al. 2012). Heron (1996) concluded that ants were resilient and even heavy grazing increased abundance and diversity relative to ungrazed grasslands in the Okanagan valley of British Columbia. Both Heron (1996) and Schmidt et al. (2012) used pitfall traps to study ants, but neither reported the abundance or diversity of carabids. Therefore, these works cannot be leveraged to assess Spence and Berg's (1984) hypothesis that ants displace carabids under certain grazing regimes.

In addition to altering habitat structure, ungulate grazers may directly compete with some arthropod herbivores. For example, research conducted in grasslands of the United States of America found that populations of pest grasshoppers (e.g., Melanoplus sanguinipes (Fabricus); Orthoptera: Acrididae) were reduced in grazed habitats compared with ungrazed habitats (O'Neill et al. 2003). They attributed their results both to altered habitat structure due to grazing, and to competition between the ungulate grazers and the grasshoppers. 
Overall, the effects of cropping practices and grazing on arthropod diversity are species specific. Further work to address these agricultural practices would be interesting and could elucidate which factors associated with grazing are the best predictors of arthropod diversity. Using a feeding guild approach may be useful for designing experiments that address specific questions about the impacts of grazing and cropping on grassland arthropods.

\section{Agricultural inputs and practices: abiotic factors that affect arthropod diversity}

In prairie agroecosystems, insecticides are available to combat pest outbreaks in all major commodities (Brook and Cutts 2017). Foliar insecticides are applied in response to insect pest outbreaks that occur during the growing season, when pest populations exceed recommended economic thresholds (Stern et al. 1959). Systemic insecticides (and fungicides) are applied as seed treatments and function by protecting seedlings from pests and diseases during stand establishment (Ripper et al. 1949). Planting insecticide treated seed does not prohibit subsequent use of foliar insecticides. Systemic insecticides are considered "environmentally soft", as they only target pests feeding on treated foliage (Ripper et al. 1949). However, many systemic insecticides registered in Canada are neonicotinoids (Brook and Cutts 2017), the most widely used insecticide chemistry worldwide (Goulson 2013). Because of their broad-spectrum range, widespread use, accumulation, and persistence, neonicotinoid insecticides used systemically may not be as environmentally safe as once thought (Goulson 2013). Their safety is under review in Europe and North America.

Herbicides and tillage are strategies used to control weeds (and some insect pests) in agroecosystems in the Prairies Ecozone. Conservation tillage, which limits soil perturbation relative to conventional tillage, is widely practiced across the prairies to prevent soil erosion and to help maintain soil moisture (Holland 2004). Chemical herbicides target certain plant growth processes, such as amino acid synthesis (Brook and Cutts 2017). Herbicides may be applied in spring (pre-emergence) and during the growing season (post-emergence).
In the Canadian Prairies, ground beetles are one of the best-studied taxa in terms of their response to agricultural inputs. Baseline carabid data are available, especially in Manitoba, from the work conducted by Norman Criddle (Holliday et al. 2014). This historical record can be used in longitudinal studies comparing past and present carabid assemblages. Different species and guilds of Carabidae respond to agricultural inputs in disparate ways, complicating experimentation, analysis, and synthesis. This information needs to be incorporated into future studies assessing the impacts of agricultural inputs so that appropriate guilds are selected for evaluation. Four generalisations can be made based on carabid research conducted in the Canadian Prairies (and elsewhere):

1. Insecticide use generally decreases the activity and density of carabids (Floate et al. 1989; Bourassa et al. 2008). In a crop rotation study, Bourassa et al. (2008) observed that the activity density of carabid species, based on pitfall trap data, was significantly less in the insecticide treated potato crop relative to other crops in the rotation that received no insecticides. In a study of alfalfa fields managed for hay production (no insecticide application) and for seed production (with insecticide application), Uddin (2005) noted that the overall carabid assemblage did not differ between the two management systems; however, some species were negatively affected by the spring insecticide application, including Poecilus corvus and Agonum cupreum Dejean (Coleoptera: Carabidae). In a similar study in Saskatchewan, high-input and organically managed fields supported carabid assemblages of equal diversity and abundance (Melnychuk et al. 2003). Floate et al. (2007) observed no negative or positive effects of corn engineered to target Lepidoptera by expressing Bacillus thuringiensis Berliner (Bacillales: Bacillaceae) $(B t)$ endotoxins on ground beetles in southern Alberta and concluded that $B t$ corn has limited effects on non-target carabids. The impacts of crops genetically engineered to express $B t$ endotoxins on non-target species and arthropod biodiversity have been well studied since their introduction (e.g., Shelton et al. 2002; Floate et al. 2007). Compared to traditional insecticides, $B t$ crops have 
negligible impacts on non-target insects and offer a relatively benign option for insect pest management (Shelton et al. 2002).

2. Tillage affects populations of carabids; however, the effects are species specific (Cárcamo 1995). In general, carabid abundance and diversity is negatively correlated with tillage intensity (Kromp 1999). In a study conducted in fields managed with conventional and conservation tillage in Alberta, Cárcamo (1995) observed that species in the genera Agonum Linnaeus and Amara (Coleoptera: Carabidae) responded positively to tilled fields, while Pterostichus Bonelli and Bembidion (Coleoptera: Carabidae) species responded positively to reduced-tillage practices. Studies conducted in Europe suggest that the natural history of carabids is related to their response to tillage. For example, carabid species that breed in autumn were most abundant in fields ploughed in the spring, and small-bodied species benefitted from reduced tillage (Baguette and Hance 1997). From an integrated pest management perspective, conservation tillage is useful as it protects populations of beneficial insect species from disturbance.

3. Herbicide application has indirect impacts on carabid ground beetles in agroecosystems. Herbicides are associated with reduced food resources and/or habitat modification that result from changes in vegetation density or diversity (Richardson 1982; Bourassa et al. 2010). For example, Richardson (1982) observed that all common species of Carabidae observed at the Glenlea Research Farm at the University of Manitoba were reduced in herbicide treated plots that had significantly less vegetation than control plots. Bourassa et al. (2010) observed a similar effect of vegetation density on carabid beetles in Alberta, although in a rotation without herbicide application. Specifically, small ground beetle species such as Bembidion quadrimaculatum (Linnaeus) were less common in weedy fields than large species including Pterostichus melanarius (Bourassa et al. 2010).

4. Chemical and organic fertilisers have speciesspecific impacts on carabid beetle diversity and abundance. Organic fertilisers such as mulch and manure have been associated with increasing beetle populations, perhaps due to the addition of alternative prey (Humphreys and Mowat 1994; Hance 2002). Studies investigating inorganic fertilisers have reported short-term reductions in abundance followed by recovery, no negative impacts on carabid abundance, and inconsistent results between years, making conclusions difficult to draw (Hance 2002). To our knowledge, studies specific to Canada or the Prairies Ecozone are lacking.

There is less information available regarding the response of other arthropod taxa to agricultural inputs in the prairies. Tillage has negative effects on ant populations and distribution across the landscape (Robertson et al. 1994; Yates and Andrew 2011; Glasier and Acorn 2014). Insecticides are associated with decreasing ant populations (Glasier and Acorn 2014). Insecticides that inadvertently reach streams and rivers in the prairies, or that are applied to control biting flies, affect local diversity and abundance of immature Odonata and Plecoptera (Dosdall and Lehmkuhl 1989). Effects of insecticides on the adult stages of these orders are unknown. Decreasing pollinator populations are a concern worldwide; however, bee (Hymenoptera: Apocrita) distribution, population density, and diversity have been understudied in the Canadian Prairies (Sheffield et al. 2014). Bee species are diverse in their nesting and foraging habits (Sheffield et al. 2014), and may be particularly sensitive to different tillage practices, herbicide use that affects vegetation diversity, and insecticides.

In the heavily fragmented Prairies Ecozone, direct studies to quantify the impacts of agricultural inputs on arthropod biodiversity are needed, but are difficult to design, in part because reliable baseline data are not available for all taxa of interest. Other measures of agroecosystem health that indirectly assess arthropod biodiversity may be needed to assess agricultural impacts. Two phenomena associated with insecticide use could be used for this purpose: pest resurgence and secondary pest outbreaks. Both are associated with reduced populations of natural enemies resulting from non-target insecticide exposure (Croft 1990; Hardin et al.1995). These phenomena could be used as indicators of insecticide-mediated local diversity loss when location-specific historical data are not available. 


\section{Biological control arthropods as biotic inputs}

A periodic input to prairie agroecosystems is the intentional introduction of foreign arthropods for the control of arthropod pests and weeds; i.e., "classical biological control”. Unlike abiotic inputs, biological control (biocontrol) agents are expected to be selfsustaining and interactive additions to agroecosystems that exert long-term pest mitigation. As such, their long-term existence and impacts, whether positive or negative, contribute to the ecological structure and function of the agroecosystems into which they are introduced.

Although several biocontrol agents from a range of taxonomic groups have been purposely introduced to Canada, not all have become established. This is especially the case for arthropods used in the biocontrol of crop pests: only one of 19 species of Hymenoptera parasitoids introduced to target 12 exotic prairie pest species is established (De Clerck-Floate and Cárcamo 2011). The successful species, Platygaster tuberosula Kieffer (Hymenoptera: Platygasteridae), is a wasp released to control orange wheat blossom midge (Sitodiplosis mosellana Gehin; Diptera: Cecidomyiidae) (Doane et al. 2013). Although established in Saskatchewan, this species does not have a major impact on its target pest (Doane et al. 2013). Biocontrol has been attempted against three crop pests native to the prairies: wheat stem sawfly; bertha armyworm (Mamestra configurata Walker; Lepidoptera: Noctuidae); and Lygus Hahn (Hemiptera: Miridae). These attempts used introduced parasitoids of closely related (taxonomically and ecologically) foreign arthropods (i.e., "neoclassical biocontrol") (De Clerck-Floate and Cárcamo 2011). None of the three Hymenoptera parasitoids purposely introduced in these neoclassical biocontrol programmes have become established in the Canadian Prairies (De Clerck-Floate and Cárcamo 2011).

Some adventive species that were not purposefully introduced to the Canadian Prairies have reduced populations of some arthropod pests and have had an impact on arthropod communities. For example, Tetrastichus julis Walker (Hymenoptera: Eulophidae) was released in the Creston Valley of British Columbia in 2002 (Phillip 2007), and was reported in southern
Alberta in 2007 (Cárcamo et al. 2007). It appears to have kept the cereal leaf beetle (Oulema melanopus (Linnaeus); Coleoptera: Chrysomelidae) below damaging levels as observed in other parts of North America (Roberts 2016). Macroglenes penetrans (Kirby) (Hymenoptera: Pteromalidae) is another foreign parasitoid that was not deliberately released, but is now widely distributed throughout the prairies and reduces populations of wheat midge (Doane et al. 2013). Two species of foreign ladybird beetles, Coccinella septempunctata Linnaeus and Harmonia axyridis (Pallas) (Coleoptera: Coccinellidae) that were released in the United States of America for aphid (Hemiptera: Aphididae) control have moved into the prairies. Coccinella septempunctata is now the dominant coccinellid and it has been linked with displacement of native ladybird beetle species in Manitoba (Turnock et al. 2003; Acorn 2007). Harmonia axyridis is a more recent invader now present in Manitoba (Wise et al. 2002), where it is expected to have an impact on native assemblages of coccinellids (Koch and Galvan 2008).

In comparison to biocontrol efforts targeting pest arthropods, classical biocontrol programmes for weeds have been relatively successful. Approximately $72 \%$ (58 of 81 species) of the herbivorous arthropods introduced to control 29 invasive plant species from 1951 to the end of 2014 are considered established, many on weeds in the prairies (updated from De Clerck-Floate and Cárcamo 2011; Mason and Gillespie 2013; Winston et al. 2014). Of the 58 established species, the majority are Coleoptera (32 species; 55\%), Lepidoptera (11 species; 20\%), and Diptera (11 species; 20\%). Some of the 32 established beetle biocontrol agents, especially in the families Curculionidae and Chrysomelidae, occur in significant enough abundance to have caught the attention of taxonomists documenting Coleopteran diversity in Canada and Alaska (Bousquet et al. 2013).

Arthropods introduced for weed control are chosen for their host specificity, and typically demonstrate high host fidelity once released (Suckling and Sforza 2014). Therefore, their abundance and distribution follows that of their host. This is apparent for several recent successes in classical weed biocontrol in western Canada (De Clerck-Floate and Cárcamo 2011), including the root weevil (Mogulones crucifer (Pallas) (Coleoptera: Curculionidae) on houndstongue 
(Cynoglossum officinale Linnaeus; Boraginaceae) in southern rangelands of British Columbia and Alberta (De Clerck-Floate and Wikeem 2009). In this, and other successes, the biocontrol agents involved were highly mobile within heterogeneous landscapes. For example, M. crucifer easily traversed its complex forested-grassland landscape in southeastern British Columbia to find isolated patches of its host (De Clerck-Floate et al. 2005). They also behaved as ideal classical biocontrol agents by reaching outbreak population densities to reduce target weed densities.

Arthropod communities in the prairies are often hybrids in structure, composed of both remnant native grassland species and introduced species of different trophic levels. For example, the cabbage seedpod weevil (Ceutorhynchus obstrictus Marsham; Coleoptera: Curculionidae) is a dominant exotic herbivore pest of canola in southern areas of Alberta and Saskatchewan, where its natural enemies are now a mixture of native and adventive species (Dosdall et al. 2009; Cárcamo and Brandt 2017). Likewise for weed biocontrol, which is typically implemented in native grasslands invaded by extensive, near-monoculture patches of target weeds, the arthropod communities are generally simplified, weed-based assemblages of native and adventive species. In addition to deliberately introduced biocontrol agents, native and/or unintentionally introduced insects also may join the weed-associated arthropod community as herbivores (e.g., on Canada thistle, Cirsium arvense (Linnaeus) Scopoli (Asteraceae); De Clerck-Floate and Cárcamo 2011), pollinators (on Canada thistle; Theis 2006), or as parasitoids and predators that may use the introduced herbivores as hosts or as prey (see Winston et al. 2014). The simplicity of these arthropod communities is due, at least in part, to the invasive plant having escaped its arthropod natural enemies and associated ecological ties upon invading new ranges (i.e., the "enemy escape hypothesis"; Keane and Crawley 2002). Classical biocontrol reunites the invasive plant with a selective, and typically small subset of its arthropod herbivores from its native range (De Clerck-Floate and Cárcamo 2011), with care taken to minimise accidental introduction of natural enemies of the non-native biocontrol agent (Mason et al. 2017).

Although not well studied, the interspecific interactions among arthropods that structure the simple arthropod communities that include biocontrol agents can be either direct or indirect. Interspecific competition may occur between introduced herbivore biocontrol agents on the same weed species, directly affecting biocontrol success. The seed-feeding species Larinus minutus Gyllenhal (Coleoptera: Curculionidae) and Urophora affinus (Frauenfeld) (Diptera: Tephritidae), for instance, compete with each other on spotted knapweed in British Columbia (Crowe and Bourchier 2006). Arthropod natural enemies introduced for biocontrol of crop pests may also attack biocontrol agents of weeds if they are closely related to the target crop pest. This possibility has prompted development of a prerelease testing strategy for candidate entomophagous agents to avoid potential conflicts between biocontrol efforts for weeds and insects (Kuhlmann et al. 2006). For example, weevils in the subfamily Ceutorhynchinae have been introduced to control weeds in the Canadian Prairies, thus, biocontrol agents of the cabbage seedpod weevil are being carefully selected and tested before relocation from eastern Canada to the Prairie Provinces (Haye et al. 2015).

Indirect interactions of introduced arthropods for biocontrol with native members of the arthropod community are very difficult to identify, assess, and predict, and have not received much attention in Canada. The possibility of host specific biocontrol agents creating deleterious collateral impacts within native arthropod communities has been documented elsewhere (e.g., United States of America; Pearson and Callaway 2003, 2005; and Australia; Carvalheiro et al. 2008). Host specific weed biocontrol agents can indirectly compete with native arthropod herbivores on their nearby host plants if the two herbivores share natural enemies (i.e., apparent competition; Holt 1977) (Carvalheiro et al. 2008). Apparent competition occurs if generalist natural enemies respond numerically to the food surplus created when populations of biocontrol agents increase (Pearson and Callaway 2003). The indirect negative impact on native herbivores by biocontrol agents is predicted to increase where the abundance of the biocontrol agent remains elevated. This can happen for some agents that are ineffective in reducing the density of their host in a typical predator-prey population interaction (Pearson and Callaway 2005). Although several weed biocontrol agents established in the 
Canadian Prairies fall into the category of high abundance-low efficacy (Winston et al. 2014), detailed community-level studies of their effects are lacking. Similarly, little is known about the potential indirect impacts of weed biocontrol agents on native arthropods that feed on native plants closely related to the targeted foreign weed, in cases where biocontrol agents may also feed on native plant species (Louda et al. 2005).

In conclusion, arthropods introduced for biocontrol of insect pests or weeds can directly or indirectly influence communities of native arthropods in the Prairies Ecozone, but very little is known about the incidence and degree of such processes. Foreign arthropods can displace native species through competition or predation (e.g., adventive ladybird beetles). The effects of parasitoid wasps and other introduced natural enemies on arthropod communities remain to be quantified. In the case of weed biocontrol, fewer negative impacts are predicted because these agents tend to be host specific, and the target plant is a foreign species with a few native herbivores. Although careful examination of host ranges and potential impacts on non-target species before a release are standard practices of biocontrol programmes in Canada (Mason et al. 2017), greater awareness and knowledge of potential indirect impacts on native arthropod populations by introduced biocontrol arthropod agents is recommended.

\section{Conclusion}

Arthropod communities in the Canadian Prairies inhabit highly fragmented pristine grasslands and habitats disturbed by agroecosystems. These arthropods are influenced by landscape features, agricultural practices, and by abiotic and biotic inputs. Very few comprehensive ecological studies of arthropod communities have been conducted in the Prairies Ecozone. Even less work has been done to compare arthropod communities in pristine grassland habitats and disturbed agroecosystem habitats.

In contrast to native grasslands, agroecosystems are more temporally and spatially variable. Concepts from landscape ecology predict that arthropod diversity should increase with increasing non-crop area and with increasing habitat complexity. These concepts have been tested in Europe and the United States of America (e.g.,
Bianchi et al. 2005; Duflot et al. 2015), but equivalent work has yet to be completed and published for the Prairies Ecozone. Studies conducted at the landscape scale could reveal important factors affecting arthropod populations, and provide information required to develop arthropod and habitat conservation programmes.

Crop rotation is used to manage agricultural pests and affects the temporal and spatial composition of habitats used by arthropods. Crop rotation creates barriers to arthropod dispersal that are effective in managing pest arthropod populations (especially specialists), but also affect native and non-pest arthropods. The impacts of crop rotation on non-target arthropods vary depending on mobility, body size, and habitat requirements (e.g., Cárcamo and Spence 1994; Bourassa et al. 2010). Future work to understand the impacts of crop rotation on arthropods should use careful experimental designs to better control for confounding variables (i.e., agricultural inputs required for specific crops within the rotation), and should span over longer periods of time to fully assess not only the current crop in the rotation, but the changes in arthropod communities from year-to-year during the rotation.

Cattle grazing appears to influence arthropod communities in a predictable manner. Despite only a few studies, there is a consistent pattern for a range of fauna including ants, carabid beetles, and mites. Modest levels of grazing increase the abundance, and in some cases, the species diversity of arthropods relative to ungrazed sites. This pattern corresponds well with the intermediate disturbance concept that is known to structure communities in other habitats. These studies confirm that grazing, at least at moderate levels, and similar to that done by bison in the past, may be considered an integral aspect of the Prairies Ecozone.

Abiotic agricultural inputs generally have negative impacts on arthropod abundance and diversity. Carabid beetles are the best-studied non-pest arthropod group, although data regarding ants and aquatic species are available. Balancing the use of abiotic inputs to protect crops and minimising non-target effects will be key to maintain the ecosystem services that arthropods provide (Pimentel 2009). As new pest management inputs are developed and application programmes evolve, assigning a dollar value to 
ecosystem services provided by arthropods could allow farmers to simultaneously balance the costs and benefits of agricultural inputs.

Biocontrol represents a biotic input in agroecosystems. Biocontrol programmes for weeds and insect pests have been undertaken in the Canadian Prairies, with varying levels of success. Certain biocontrol agents released elsewhere have made their way to the prairies and have had negative impacts on native arthropod communities, by displacing native species (e.g., ladybird beetles; Acorn 2007). Arthropods introduced for biocontrol of agroecosystem pests are predicted to have both direct and indirect impacts, via competitive interactions, on native arthropods. Aside from a few examples, very little work has been done to assess these impacts, although precautions are taken during the introduction process to evaluate and minimise risks (Mason et al. 2017).

To protect arthropod diversity in the Canadian Prairies, and ensure agricultural sustainability, we need to learn as much as possible about our prairie agroecosystems. Our review summarises the current state of knowledge and highlights several important research gaps. In moving towards filling those gaps, it is important to learn from previous research conducted in the prairies to further refine experimental designs and arthropod sampling methods. Where appropriate, methodology successfully used elsewhere (i.e., Europe, United States of America), should be adopted. Research needs to be conducted across multiple scales. Research should also focus on important indicator species, or on arthropod response to agricultural practices at the guild level, to aid in the synthesis of research results and guide future understanding.

\section{Acknowledgements}

The authors thank Karen Mah for her assistance with literature searches and Jonathon Williams for editing an earlier version of the manuscript. We also thank two anonymous reviewers for their comments on an earlier version of the manuscript.

\section{References}

Acorn, J.H. 2007. Ladybugs of Alberta: finding the spots and connecting the dots. University of Alberta Press, Edmonton, Alberta, Canada.
Agriculture and Agri-Food Canada. 2010. Reduced-risk wireworm management in potato. Publication 11190E. Agriculture and Agri-Food Canada, Ottawa, Ontario, Canada.

Ahern, R.G. and Brewer, M.J. 2002. Effect of different wheat production systems on the presence of two parasitoids (Hymenoptera: Aphelinidae; Braconidae) of the Russian wheat aphid in the North American Great Plains. Agriculture, Ecosystems and Environment, 92: 201-210.

Altieri, M.A., Letourneau, D.K., and Risch, S.J. 1984. Vegetation diversity and insect pest outbreaks. Critical Reviews in Plant Sciences, 2: 131-169.

Andow, D. 1983. The extent of monoculture and its effect on insect pest populations with particular reference to wheat and cotton. Agriculture, Ecosystems and Environment, 9: 25-35.

Baguette, M. and Hance, T. 1997. Carabid beetles and agricultural practices: influence of soil ploughing. Biological Agriculture and Horticulture, 15: 185-190.

Benton, T.G., Vickery, J.A., and Wilson, J.D. 2003. Farmland biodiversity: is habitat heterogeneity the key? Trends in Ecology \& Evolution, 18: 182-188.

Beres, B., Dosdall, L., Weaver, D., Cárcamo, H., and Spaner, D. 2011. Biology and integrated management of wheat stem sawfly and the need for continuing research. The Canadian Entomologist, 143: 105-125.

Bertrand, C., Burel, F., and Baudry, J. 2016. Spatial and temporal heterogeneity of the crop mosaic influences carabid beetles in agricultural landscapes. Landscape Ecology, 31: 451-466.

Bianchi, F., Booij, C., and Tscharntke, T. 2006. Sustainable pest regulation in agricultural landscapes: a review on landscape composition, biodiversity and natural pest control. Proceedings of the Royal Society B: Biological Sciences, 273: 1715-1727.

Bianchi, F.J.J.A., van Wingerden, W.K.R.E., Griffioen, A.J., van der Veen, M., van der Straten, M.J.J., Wegman, R.M.A., and Meeuwsen, H.A.M. 2005. Landscape factors affecting the control of Mamestra brassicae by natural enemies in Brussels sprout. Agriculture, Ecosystems and Environment, 107: 145-150.

Biodiversity Institute of Ontario. 2013. DNA Barcodebased assessment of arthropod diversity in Canada's National Parks: progress report for Grasslands National Park. Bio-Inventory and Collections Unit, Biodiversity Institute of Ontario, University of Guelph, Guelph, Ontario, Canada. Pp. 1-13.

Boiteau, G., Picka, J., and Watmough, J. 2008. Potato field colonization by low-density populations of Colorado potato beetle as a function of crop rotation distance. Journal of Economic Entomology, 101: 1575-1583.

Bourassa, S., Cárcamo, H.A., Larney, F.J., and Spence, J.R. 2008. Carabid assemblages (Coleoptera: Carabidae) in a rotation of three different crops in southern Alberta, Canada: a comparison of sustainable and conventional farming. Environmental Entomology, 37: 1214-1223. 
Bourassa, S., Cárcamo, H.A., Spence, J.R., Blackshaw, R.E., and Floate, K. 2010. Effects of crop rotation and genetically modified herbicide-tolerant corn on ground beetle diversity, community structure, and activity density. The Canadian Entomologist, 142: 143-159.

Bousquet, Y., Bouchard, P., Davies, A.E., and Sikes, D.S. 2013. Checklist of beetles (Coleoptera) of Canada and Alaska. Pensoft Series Faunistica 109, Pensoft, Sofia, Bulgaria.

Broatch, J.S. 2008. Root maggot and beneficial insect dynamics in response to weed populations in canola. Ph.D. thesis. University of Alberta, Edmonton, Alberta, Canada.

Brook, H. and Cutts, M. 2017. Crop Protection 2017. Alberta Agriculture and Forestry, Edmonton, Alberta, Canada.

Brust, G.E. and King, L.R. 1994. Effects of crop rotation and reduced chemical inputs on pests and predators in maize agroecosystems. Agriculture, Ecosystems and Environment, 48: 77-89.

Bullock, D.G. 1992. Crop rotation. Critical Reviews in Plant Sciences, 11: 309-326.

Butts, R.A., Floate, K.D., David, M., Blackshaw, R.E., and Burnett, P.A. 2003. Influence of intercroppng canola or pea with barley on assemblages of ground beetles (Coleoptera: Carabidae). Environmental Entomology, 32: 535-541.

Campbell, C., Zentner, R., Gameda, S., Blomert, B., and Wall, D. 2002. Production of annual crops on the Canadian prairies: trends during 1976-1998. Canadian Journal of Soil Science, 82: 45-57.

Capinera, J.L. 2005. Relationships between insect pests and weeds: an evolutionary perspective. Weed Science, 53: 892-901.

Cárcamo, H.A. 1995. Effect of tillage on ground beetles (Coleoptera: Carabidae): a farm-scale study in central Alberta. The Canadian Entomologist, 127: 631-639.

Cárcamo, H. and Brandt, R. 2017. Cabbage seedpod weevil management. In Integrated management of insect pests on canola and other brassica oilseed crops. Edited by V.P. Gadi Reddy. CABI, Boston, Massachusetts, United States of America. Pp. 77-87.

Cárcamo, H., Dosdall, L., and Larson, T. 2007. Phenology and parasitism of the cereal leaf beetle in Alberta [online]. In Minutes of the 47th annual meeting of the Western Committee on Crop Pests, Penticton, British Columbia, 18 October 2007. P. 24. Available from www.westernforum.org/WCCP\% 20Minutes.html [accessed 25 March 2017].

Cárcamo, H.A., Niemalä, J.K., and Spence, J.R. 1995. Farming and ground beetles: effects of agronomic practice on populations and community structure. The Canadian Entomologist, 127: 123-140.

Cárcamo, H.A. and Spence, J.R. 1994. Crop type effects on the activity and distribution of ground beetles (Coleoptera: Carabidae). Environmental Entomology, 23: 684-692.
Carvalheiro, L.G., Buckley, Y.M., Ventim, R., Fowler, S.V., and Memmott, J. 2008. Apparent competition can compromise the safety of highly specific biocontrol agents. Ecology Letters, 11: 690-700.

Chaplin-Kramer, R., de Valpine, P., Mills, N.J., and Kremen, C. 2013. Detecting pest control services across spatial and temporal scales. Agriculture, Ecosystems and Environment, 181: 206-212.

Chaplin-Kramer, R., O’Rourke, M.E., Blitzer, E.J., and Kremen, C. 2011. A meta-analysis of crop pest and natural enemy response to landscape complexity. Ecology Letters, 14: 922-932.

Chliboyko, J. 2010. A prairie still standing tall, barely [online]. Canadian National Geographic. Available from: www.canadiangeographic.ca/article/prairiestill-standing-tall-barely [accessed 7 March 2017].

Clapperton, M.J., Kanashiro, D.A., and Behan-Pelletier, V.M. 2002. Changes in abundance and diversity of microarthropods associated with fescue prairie grazing regimes. Pedobiologia, 46: 496-511.

Croft, B.A. 1990. Arthropod biological control agents and pesticides. Wiley, New York, New York, United States of America.

Crowe, M.L. and Bourchier, R.S. 2006. Interspecific interactions between the gall-fly Urophora affinis Frfld. (Diptera: Tephritidae) and the weevil Larinus minutus Gyll. (Coleoptera: Curculionidae), two biological control agents released against spotted knapweed, Centaurea stobe ssp. micranthos. Biocontrol Science and Technology, 16: 417-430.

De Clerck-Floate, R. and Cárcamo, H. 2011. Biocontrol arthropods: new denizens of Canada's grassland agroecosystems. In Arthropods of Canadian grasslands (Volume 2: inhabitants of a changing landscape). Edited by K. Floate. Biological Survey of Canada, Ottawa, Ontario, Canada. Pp. 291-322.

De Clerck-Floate, R. and Wikeem, B. 2009. Influence of release size on establishment and impact of a root weevil for the biocontrol of houndstongue (Cynoglossum officinale). Biocontrol Science and Technology, 19: 169-183.

De Clerck-Floate, R.A., Wikeem, B., and Bourchier, R.S. 2005. Early establishment and dispersal of the weevil, Mogulones cruciger (Coleoptera: Curculionidae) for biological control of houndstongue (Cynoglossum officinale) in British Columbia, Canada. Biocontrol Science and Technology, 15: 173-190.

Doane, J.F., Olfert, O.O., Elliott, R.H., Hartley, S., and Meers, S. 2013. Sitodiplosis mosellana (Géhin), orange wheat blossom midge (Diptera: Cecidomyiidae). In Biological control programmes in Canada 2001-2012. Edited by P.G. Mason and D.R. Gillespie. CABI Publishing, Wallingford, Oxon, United Kingdom. Pp. 272-276.

Dosdall, L.M., Gibson, G.A.P., Olfert, O.O., and Mason, P.G. 2009. Responses of Chalcidoidea (Hymenoptera) parasitoids to invasion of the cabbage seedpod weevil (Coleoptera: Curculionidae) in western Canada. Biological Invasions, 11: 109-125. 
Dosdall, L.M., Harker, K., O’Donovan, J., Blackshaw, R., Kutcher, H., Gan, Y., and Johnson, E. 2012. Crop sequence effects on root maggot (Diptera: Anthomyiidae: Delia spp.) infestations in canola. Journal of Economic Entomology, 105: 1261-1267.

Dosdall, L.M. and Lehmkuhl, D.M. 1989. Drift of aquatic insects following methoxychlor treatment of the Saskatchewan River system. The Canadian Entomologist, 121: 1077-1096.

Dosdall, L.M., Soroka, J.J., and Olfert, O. 2011. The diamondback moth in canola and mustard: current pest status and future prospects. Prairie Soils and Crops, 4: 66-76.

Duflot, R., Aviron, S., Ernoult, A., Fahrig, L., and Burel, F. 2015. Reconsidering the role of 'semi-natural habitat' in agricultural landscape biodiversity: a case study. Ecological Research, 30: 75-83.

Ellsbury, M.M., Powell, J.E., Forcella, F., Woodson, W.D., Clay, S.A., and Riedell, W.E. 1998. Diversity and dominant species of ground beetle assemblages (Coleoptera: Carabidae) in crop rotation and chemical input systems for the Northern Great Plains. Annals of the Entomological Society of America, 91: 619-625.

Esser, A.D., Milosavljević, I., and Crowder, D.W. 2015. Effects of neonicotinoids and crop rotation for managing wireworms in wheat crops. Journal of Economic Entomology, 108: 1786-1794.

Fahrig, L., Baudry, J., Brotons, L., Burel, F.G., Crist, T.O., Fuller, R.J., et al. 2011. Functional landscape heterogeneity and animal biodiversity in agricultural landscapes. Ecology Letters, 14: 101-112.

Fahrig, L., Girard, J., Duro, D., Pasher, J., Smith, A., Javorek, S., et al. 2015. Farmlands with smaller crop fields have higher within-field biodiversity. Agriculture, Ecosystems and Environment, 200: 219-234.

Flick, T., Feagan, S., and Fahrig, L. 2012. Effects of landscape structure on butterfly species richness and abundance in agricultural landscapes in eastern Ontario, Canada. Agriculture, Ecosystems and Environment, 156: 123-133.

Flint, M.L. and Roberts, P.A. 1988. Using crop diversity to manage pest problems: some California examples. American Journal of Alternative Agriculture, 3: 163-167.

Floate, K.D. 2011. Arthropods of the Canadian grasslands (Volume 2: inhabitants of a changing landscape). Biological Survey of Canada, Ottawa, Ontario, Canada.

Floate, K.D., Cárcamo, H.A., Blackshaw, R.E., Postman, B., and Bourassa, S. 2007. Response of ground beetle (Coleoptera: Carabidae) field populations to four years of Lepidoptera-specific $B t$ corn production. Environmental Entomology, 36: 1269-1274.

Floate, K.D., Elliot, R.H., Doane, J.F., and Gillott, C. 1989. Field bioassay to evaluate contact and residual toxicities of insecticides to carabid beetles (Coleoptera: Carabidae). Journal of Economic Entomology, 82: $1543-1547$.
Floate, K.D., Shorthouse, J.D., Giberson, D.J., and Carcamo, H.A. 2017. Arthropods of Canadian grasslands: a retrospective of a 40-year project of the Biological Survey of Canada. The Canadian Entomologist, doi.org/10.4039/tce.2017.46.

French, B.W., Elliott, N.C., and Berberet, R.C. 1998. Reverting conservation reserve program lands to wheat and livestock production: effects on ground beetle (Coleoptera: Carabidae) assemblages. Environmental Entomology, 27: 1323-1335.

Gardiner, M.M., Landis, D.A., Gratton, C., Schmidt, N., O’Neal, M., Mueller, E., et al. 2009. Landscape composition influences patterns of native and exotic lady beetle abundance. Diversity and Distributions, 15: 554-564.

Gardiner, M.M., Landis, D.A., Gratton, C., Schmidt, N., O’Neal, M., Mueller, E., et al. 2010. Landscape composition influences the activity density of Carabidae and Arachnida in soybean fields. Biological Control, 55: 11-19.

Gillespie, R.L., Roberts, D.E., and Bentley, E.M. 1997. Population dynamics and dispersal of wheat curl mites (Acari: Eriophyidae) in north central Washington. Journal of the Kansas Entomological Society, 70: $361-364$.

Glasier, J.R.N. and Acorn, J.H. 2014. An annotated list of ants (Hymenoptera: Formicidae) from the grasslands of Alberta and Saskatchewan. In Arthropods of Canadian grasslands (Volume 4: biodiversity and systematics, part 2). Edited by D.J. Giberson and H. A. Cárcamo, Biological Survey of Canada Monographs 6, Biological Survey of Canada, Ottawa, Ontario, Canada. Pp. 299-314.

Goulson, D. 2013. An overview of the environmental risks posed by neonicotinoid insecticides. Journal of Applied Ecology, 50: 977-987.

Hall, P.W., Catling, P.M., and Lafontaine, J.D. 2011. Insects at risk in the prairie region. In Arthropods of the Canadian grasslands (Volume 2: inhabitants of a changing landscape). Edited by K. Floate. Biological Survey of Canada, Ottawa, Ontario, Canada. Pp. 323-349.

Hance, T. 2002. Impact of cultivation and crop husbandry practices. In The agroecology of carabid beetles. Edited by J.M. Holland. Intercept, Andover, United Kingdom. Pp. 231-249.

Hardin, M.R., Benrey, B., Coll, M., Lamp, W.O., Roderick, G.K., and Barbosa, P. 1995. Arthropod pest resurgence: an overview of potential mechanisms. Crop Protection, 14: 3-18.

Harper, A.M. 1988. Insects and mites on alfalfa in Alberta. Technical Bulletin 1988-3E, Lethbridge Research Station Contribution Number 12. Agriculture Canada, Government of Canada, Ottawa, Ontario, Canada.

Haye, T., Mason, P.G., Gillespie, D.R., Miall, J.H., Gibson, G.A.P., Diaconu, A., et al. 2015. Determining the host specificity of the biological control agent Trichomalus perfectus (Hymenoptera: Pteromalidae): the importance of ecological host range. Biocontrol Science and Technology, 25: 21-47. 
Heron, J.M. 1996. The effect of grazing on ant (Hymenoptera: Formicidae) diversity in the south Okanagan grasslands. M.Sc. thesis. University of British Columbia, Vancouver, British Columbia, Canada.

Holland, J. and Fahrig, L. 2000. Effect of woody borders on insect density and diversity in crop fields: a landscape-scale analysis. Agriculture, Ecosystems and Environment, 78: 115-122.

Holland, J.M. 2004. The environmental consequences of adopting conservation tillage in Europe: reviewing the evidence. Agriculture, Ecosystems and Environment, 103: 1-25.

Holliday, N.J., Floate, K.D., Cárcamo, H., Pollock, D.A., Stjernberg, A., and Roughley, R.E. 2014. Ground beetles (Coleoptera: Carabidae) of the prairie grasslands of Canada. In Arthropods of Canadian grasslands (volume 4: biodiversity and systematics, part 2). Edited by D.J. Giberson and H.A. Cárcamo. Biological Survey of Canada Monograph Series 6. Biological Survey of Canada, Ottawa, Ontario, Canada. Pp. 1-86.

Holt, R.D. 1977. Predation, apparent competition, and structure of prey communities. Theoretical Population Biology, 12: 197-229.

Holzschultz, A., Dormann, C.F., Tscharntke, T., and Steffan-Dewenter, I. 2011. Expansion of massflowering crops leads to transient pollinator dilution and reduced wild plant pollination. Proceedings of the Royal Society of London B: Biological Sciences, 278: 3444-3451.

Humble, S.M. 2001. Weeds and ground beetles (Coleoptera: Carabidae) as influenced by crop rotation type and crop input management. M.Sc. thesis. University of Manitoba, Winnipeg, Manitoba, Canada.

Hummel, J.D., Dosdall, L.M., Clayton, G.W., Harker, K.N., and O’Donovan, J.T. 2012. Ground beetle (Coleoptera: Carabidae) diversity, activity density, and community structure in a diversified agroecosystem. Environmental Entomology, 41: 72-80.

Humphreys, I.C. and Mowat, D.J. 1994. Effect of some organic treatments on predators (Coleoptera: Carabidae) of cabbage root fly, Delia radicum (L.) (Diptera: Anthomyiidae), and on alternative prey species. Pedobiologia, 38: 513-518.

Jonsen, I.D. and Fahrig, L. 1997. Response of generalist and specialist insect herbivores to landscape spatial structure. Landscape Ecology, 12: 185-197.

Keane, R.M. and Crawley, M.J. 2002. Exotic plant invasions and the enemy release hypothesis. Trends in Ecology \& Evolution, 17: 164-170.

Koch, R.L. and Galvan, T.L. 2008. Bad side of a good beetle: the North American experience with Harmonia axyridis. BioControl, 53: 23-35.

Kremen, C. and M'Gonigle, L.K. 2015. Small-scale restoration in intensive agricultural landscapes supports more specialized and less mobile pollinator species. Journal of Applied Ecology, 52: 602-610.
Kromp, B. 1999. Carabid beetles in sustainable agriculture: a review on pest control efficiency, cultivation impacts and enhancement. Agriculture, Ecosystems and Environment, 74: 187-228.

Kuhlmann, U., Mason, P.G., Hinz, H.L., Blossey, B., De Clerck-Floate, R.A., Dosdall, L.M., et al. 2006. Avoiding conflicts between insect and weed biological control: selection of non-target species to assess host specificity of cabbage seedpod weevil parasitoids. Journal of Applied Entomology, 130: 129-141.

Landis, D.A. 2017. Designing agricultural landscapes for biodiversity-based ecosystem services. Basic and Applied Ecology, 18: 1-12.

Landis, D.A., Wratten, S.D., and Gurr, G.M. 2000. Habitat management to conserve natural enemies of arthropod pests in agriculture. Annual Review of Entomology, 45: 175-201.

Louda, S.M., Rand, T.A., Russell, F.L., and Arnett, A.E. 2005. Assessment of ecological risks in weed biocontrol: input from retrospective ecological analyses. Biological Control, 35: 253-264.

Maisonhaute, J.-É., Labrie, G., and Lucas, E. 2017. Direct and indirect effects of the spatial context on the natural biocontrol of an invasive crop pest. Biological Control, 106: 64-76.

Maisonhaute, J.-É., Peres-Neto, P., and Lucas, E. 2010. Influence of agronomic practices, local environment and landscape structure on predatory beetle assemblage. Agriculture, Ecosystems and Environment, 139: 500-507.

Martens, J.R.T., Entz, M.H., and Wonneck, M.D. 2015. Redesigning Canadian prairie cropping systems for profitability, sustainability, and resilience. Canadian Journal of Plant Science, 95: 1049-1072.

Mason, P.G., De Clerck-Floate, R.A., Gallant, B., Gillespie, D.R., Floate, K., Bourchier, R., and Boivin, G. 2017. Guide for the first time importation and release of arthropod biocontrol agents in Canada. Agriculture and Agri-Food Canada Publication, Ottawa, Ontario, Canada.

Mason, P.G. and Gillespie, D.R. 2013. Biological control programmes in Canada 2001-2012. CABI Publishing, Wallingford, Oxon, United Kingdom.

McLaughlin, A. and Mineau, P. 1995. The impact of agricultural practices on biodiversity. Agriculture, Ecosystems and Environment, 55: 201-212.

Melnychuk, N.A., Olfert, O., Youngs, B., and Gillott, C. 2003. Abundance and diversity of Carabidae (Coleoptera) in different farming systems. Agriculture, Ecosystems and Environment, 95: 69-72.

Mitchell, M.G.E., Bennett, E.M., and Gonzalez, A. 2014. Agricultural landscape structure affects arthropod diversity and arthropod-derived ecosystem services. Agriculture, Ecosystems and Environment, 192: 144-151.

Olfert, O., Cárcamo, H., and Pepper, J. 2005. Insect pests and arthropod diversity in field margins of western Canada. In Field boundary habitats: implications for weed, insect and disease management. Topics in Canadian weed science, volume 1. Edited by A.G. Thomas. Canadian Weed Science Society, SainteAnne-de-Bellevue, Quebec, Canada. Pp. 135-163. 
Olfert, O., Johnson, G.D., Brandt, S.A., and Thomas, A.G. 2002. Use of arthropod diversity and abundance to evaluate cropping systems. Agronomy Journal, 94: 210-216.

O’Neill, K.M., Olson, B.E., Rolston, M.G., Wallander, R., Larson, D.P., and Seibert, C.E. 2003. Effects of livestock grazing on rangeland grasshopper (Orthoptera: Acrididae) abundance. Agriculture, Ecosystems and Environment, 97: 51-64.

Osler, G.H.R., Harrison, L., Kanashiro, D.K., and Clapperton, M.J. 2008. Soil microarthropod assemblages under different arable crop rotations in Alberta, Canada. Applied Soil Ecology, 38: 71-78.

Pearson, D.E. and Callaway, R.M. 2003. Indirect effects of host-specific biological control agents. Trends in Ecology \& Evolution, 18: 456-461.

Pearson, D.E. and Callaway, R.M. 2005. Indirect nontarget effects of host-specific biological control agents: Implications for biological control. Biological Control, 35: 288-298.

Pepper, J.L. 1999. Diversity and community assemblages of ground-dwelling beetles and spiders on fragmented grasslands of southern Saskatchewan. M.Sc. thesis. University of Regina, Regina, Saskatchewan, Canada.

Phillip, H. 2007. Biocontrol of the cereal leaf beetle [online]. In Minutes of the 47th annual meeting of the Western Committee of Crop Pests, Penticton, British Columbia, 18 October 2007 [online]. P. 5. Available from www.westernforum.org/WCCP\% 20Minutes.html [accessed 25 March 2017].

Pimentel, D. 2009. Environmental and economic costs of the application of insecticides primarily in the United States. In Integrated pest management: innovation-development processes. Edited by R. Peshin and A.K. Dhawan. Springer Science and Business Media, Dordrecht, The Netherlands. Pp. 89-111.

Price, P.W. 1976. Colonization of crops by arthropods: non-equilibrium communities in soybean fields. Environmental Entomology, 5: 605-611.

Rand, T.A., Waters, D.K., Blodgett, S.L., Knodel, J.J., and Harris, M.O. 2014. Increased area of a highly suitable host crop increases herbivore pressure in intensified agricultural landscapes. Agriculture, Ecosystems and Environment, 186: 135-143.

Richardson, R.J. 1982. The effects of habitat disturbance on the occurrence of carabid beetles. M.Sc. thesis. University of Manitoba, Winnipeg, Manitoba, Canada.

Ripper, W.E., Greenslade, R.M., and Lickerish, L.A. 1949. Combined chemical and biological control of insects by means of a systemic insecticide. Nature, 163: 787-789.

Roberts, D.E. 2016. Classical biological control of the cereal leaf beetle, Oulema melanopus (Coleoptera: Chrysomelidae) in Washington State and role of field insectaries, a review. Biocontrol Science and Technology, 26: 877-893.
Robertson, L.N., Kettle, B.A., and Simpson, G.B. 1994. The influence of tillage practices on soil microfauna in a semiarid agroecosystem in northeastern Australia. Agriculture, Ecosystem and Environment, 48: $149-152$.

Rowe, J.S. 1990. Home place: essays on ecology. Canadian Parks and Wilderness Society. Henderson Book Series Number 12, NeWest Publishers Limited, Edmonton, Alberta, Canada.

Schellhorn, N.A., Gagic, V., and Bommarco, R. 2015. Time will tell: resource continuity bolsters ecosystem services. Trends in Ecology \& Evolution, 30: 524-530.

Schmidt, A.C., Fraser, L.H., Carlyle, C.N., and Bassett, E.R.L. 2012. Does cattle grazing affect ant abundance and diversity in temperate grasslands? Rangeland Ecology and Management, 65: 292-298.

Schuman, G.E., Janzen, H.H., and Herrick, J.E. 2002. Soil carbon dynamics and potential carbon sequestration by rangelands. Environmental Pollution, 116: 391-396.

Sexson, D.L. and Wyman, J.A. 2005. Effect of crop rotation distance on populations of Colorado potato beetle (Coleoptera: Chrysomelidae): development of areawide Colorado potato beetle pest management strategies. Journal of Economic Entomology, 98: 716-724.

Sheffield, C.S., Frier, S.D., and Dumesh, S. 2014. The bees (Hymenoptera: Apoidea, Apiformes) of the Prairies Ecozone, with comparisons to other grasslands of Canada. In Arthropods of Canadian grasslands (volume 4: biodiversity and systematics, part 2). Edited by D.J. Giberson and H.A. Cárcamo. Biological Survey of Canada Monograph Series 6. Biological Survey of Canada, Ottawa, Ontario, Canada. Pp. 427-467.

Shelton, A.M., Zhao, J.-Z., and Roush, R.T. 2002. Economic, ecological, food safety, and social consequences of the deployment of $B t$ transgenic plants. Annual Review of Entomology, 47: 845-881.

Shorthouse, J.D. 2010. Ecoregions of Canada's prairie grasslands. In Arthropods of Canadian grasslands, volume 1: ecology and interactions in grassland habitats. Edited by J.D. Shorthouse and K.D. Floate. Biological Survey of Canada, Ottawa, Ontario, Canada. Pp. 53-81.

Smith, R.G., Gross, K.L., and Robertson, G.P. 2008. Effects of crop diversity on agroecosystem function: crop yield response. Ecosystems, 11: 355-366.

Spence, J.R. and Berg, N. 1984. Our beef and grassland beetles. Arthropods of Canadian Grasslands. Newsletter of Biological Survey of Canada (Terrestrial Arthropods), 2: 5-6.

Spencer, J.L., Hughson, S.A., and Levine, E. 2014. Insect resistance to crop rotation. In Insecticide resistance management: biology, economics, and prediction, 2nd edition. Edited by D.W. Onstad. Elsevier, London, United Kingdom. Pp. 233-278. 
Statistics Canada. 2012. CANSIM database, Table 0040002 - Census of Agriculture, total area of farms and use of farm land, Canada and provinces [online]. Available from www5.statcan.gc.ca/cansim/a05?lan$\mathrm{g}=$ eng\&id=0040002 [accessed 17 February 2017].

Stern, V.M., Smith, R.F., van den Bosch, R., and Hagen, K.S. 1959. The integration of chemical and biological control of the spotted alfalfa aphid. Part I. The integrated control concept. Hilgardia, 29: 81-101.

Stjernberg, A. 2011. The effect of twice-over rotational cattle grazing on the ground beetles (Coleoptera: Carabidae) and spiders (Araneae) on the Yellow Quill Mixed Grass Prairie Preserve. M.Sc. thesis. University of Manitoba, Winnipeg, Manitoba, Canada.

Suckling, D.M. and Sforza, R.F.H. 2014. What magnitude are observed non-target impacts from weed biocontrol? Public Library of Science One, 9: e84847.

Thies, C., Roschewitz, I., and Tscharntke, T. 2005. The landscape context of cereal aphid-parasitoid interactions. Proceedings of the Royal Society B: Biological Sciences, 272: 203-210.

Theis, N. 2006. Fragrance of Canada thistle (Cirsium arvense) attracts both floral herbivores and pollinators. Journal of Chemical Ecology, 32: 917-927.

Tscharntke, T., Karp, D.S., Chaplin-Kramer, R., Batary, P., DeClerck, F., Gratton, C., et al. 2016. When natural habitat fails to enhance biological pest control - five hypotheses. Biological Conservation, 204: 449-458.

Tscharntke, T., Steffan-Dewenter, I., Kruess, A., and Thies, C. 2002. Contribution of small habitat fragments to conservation of insect communities of grassland-cropland landscapes. Ecological Applications, 12: 354-363.

Tscharntke, T., Tylianakis, J.M., Rand, T.A., Didham, R.K., Fahrig, L., Batáry, P., et al. 2012. Landscape moderation of biodiversity patterns and processes eight hypotheses. Biological Reviews, 87: 661-685.

Turnock, W.J., Wise, I.L., and Matheson, F.O. 2003. Abundance of some native coccinellines (Coleoptera: Coccinellidae) before and after the appearance of Coccinella septempunctata. The Canadian Entomologist, 135: 391-404.

Uddin, M.J. 2005. Insects of alfalfa in Manitoba with particular reference to Lygus spp., Adelphocoris lineolatus (Hemiptera: Miridae) and Acyrthosiphon pisum (Homoptera: Aphididae) and their natural enemies. Ph.D. thesis. University of Manitoba, Winnipeg, Manitoba, Canada. van Herk, W.G. and Vernon, R.S. 2014. Click beetles and wireworms (Coleoptera: Elateridae) of Alberta, Saskatchewan, and Mantiba. In Arthropods of Canadian grasslands (volume 4): biodiversity and systematics, part 2. Edited by D.J. Giberson and H.A. Cárcamo. Biological Survey of Canada Monograph Series 6. Biological Survey of Canada, Ottawa, Ontario, Canada. Pp. 87-115.

Veres, A., Petit, S., Conord, C., and Lavigne, C. 2013. Does landscape composition affect pest abundance and their control by natural enemies? A review. Agriculture, Ecosystems and Environment, 166: 110-117.

Werling, B.P., Dickson, T.L., Isaacs, R., Gaines, H., Gratton, C., Gross, K.L., et al. 2014. Perennial grasslands enhance biodiversity and multiple ecosystem services in bioenergy landscapes. Proceedings of the National Academy of Sciences, 111: 1652-1657.

Wiedenmann, R.N. and Smith, J.W. 1997. Attributes of natural enemies in ephemeral crop habitats. Biological Control, 10: 16-22.

Willis, R.B., Abney, M.R., Holmes, G.J., Schultheis, J.R., and Kennedy, G.G. 2010. Influence of preceding crop on wireworm (Coleoptera: Elateridae) abundance in the coastal plain of North Carolina. Journal of Economic Entomology, 103: 2087-2093.

Winston, R.L., Schwarzländer, M., Hinz, H.L., Day, M.D., Cock, M.J.W., and Julien, M.H. 2014. Biological control of weeds: a world catalogue of agents and their target weeds, 5th edition. FHTET-2014-04. Forest Health Technology Enterprise Team, United States Department of Agriculture Forest Service, Morgantown, West Virginia, United States of America.

Wise, I.L., Turnock, W.J., and Roughley, R.H. 2002. New records of coccinelline species in Manitoba (Coleoptera: Coccinellidae). Proceedings of the Entomological Society of Manitoba, 57: 5-10.

Wissinger, S.A. 1997. Cyclic colonization in predictably ephemeral habitats: a template for biological control in annual crop systems. Biological Control, 10: $4-15$.

Yates, F. 1954. The analysis of experiments containing different crop rotations. Biometrics, 10: 324-346.

Yates, M. and Andrew, N.R. 2011. Comparison of ant community composition across different land-use types: assessing morphological traits with more common methods. Australian Journal of Entomology, 50: 118-124. 